\title{
Reproduction and development of Calanus finmarchicus, C. glacialis and C. hyperboreus in the Barents Sea
}

\author{
W. Melle*, H. R. Skjoldal \\ Institute of Marine Research, Nordnesgt. 50, N-5024 Bergen, Norway
}

\begin{abstract}
The aim of this study is to examine the reproduction and development of Calanus finmarchicus, C. glacialis and C. hyperboreus in relation to the timing and progress of the phytoplankton spring bloom in different water masses of the Barents Sea. From 1986 to 1988, 8 cruises were conducted, covering Atlantic water in central parts of the Barents Sea and the Polar front region in the north. During the cruises hydrography, nutrients, chlorophyll and abundances of eggs, nauplii and copepodites were mapped. In the Polar front region stabilisation of the water column was caused by ice melting and a surface layer of melt-water. The phytoplankton bloom was initiated in April, more than a month earlier than in Atlantic water. A close relationship was found between phytoplankton spring bloom development and egg production of $C$. glacialis. Egg production of $C$. finmarchicus did not match the spring bloom and peaked here during the decline of the bloom, probably due to late development of the overwintered stock. Mis-match between egg production and the phytoplankton bloom due to late development may be the main factor making C. finmarchicus an expatriate in the Arctic. In Atlantic water masses stabilisation of the water column was probably caused by formation of a thermocline due to atmospheric warming, and development of the phytoplankton spring bloom was closely related to this process. A strong correlation between rate of egg production and water column chlorophyll content and a high fraction of adult females in the populations before spawning of both $C$. finmarchicus and C. glacialis indicated a functional relationship between egg production and food supply. C. finmarchicus had a predominantly 1 yr life cycle within the study area. From copepodite stage distribution the population of $C$. glacialis was judged to contain individuals having both 1 yr and 2 yr life cycles, and CIV to be a resting stage during winter. The fraction of the population having a life cycle shorter than 2 yr was highest in Atlantic water masses. C. hyperboreus started reproducing before February, showing a pre-bloom spawning strategy. Nauplii older than NIII, which may be the first feeding stage, did not occur in the samples until the food concentrations increased during the spring bloom. A secondary egg production during the bloom was probably important, and part of the population seemed to have a reproductive strategy similar to that of $C$. finmarchicus and $C$. glacialis.
\end{abstract}

KEY WORDS: Reproduction - Egg production - Development - Life cycle P Phytoplankton spring bloom - Calanus

\section{INTRODUCTION}

Three species of the genus Calanus are common in the Barents Sea. C. finmarchicus dominates the zooplankton biomasses of the Atlantic and coastal water masses in the southern and central Barents Sea (Man-

•E-mail: webjoern.melle@imr.no teufel 1938, Jaschnov 1970, Hassel 1986, Hassel et al. 1991, Tande 1991), while C. glacialis dominates the zooplankton biomass of the Arctic water masses in the north (Jaschnov 1958, 1970, Tande et al. 1985, Hassel 1986, Hassel et al. 1991, Tande 1991). C. hyperboreus generally occurs in low numbers in the Barents Sea but is most abundant in Arctic water masses (Hirche \& Mumm 1992). 
Egg production in Calanus finmarchicus has been shown to depend on an external food supply and egg production rate increases with increasing algae and chlorophyll concentrations (Marshall \& Orr 1952, 1953, Runge 1985, Hirche 1990, Smith 1990, Diel \& Tande 1992, Plourde \& Runge 1993, Hirche et al. 1997). Egg production rate also increases with increasing temperature (Runge 1985, Hirche et al. 1997), but the separate effects of temperature and food are not easily distinguished in field investigations. For ecological studies we are interested in time series relating rate of egg production to the seasonal cycle of primary production within well-defined ecological regions. More or less complete time series from inshore sites have shown that rate of egg production of $C$. finmarchicus follows the phytoplankton spring bloom dynamics (Diel \& Tande 1992, Plourde \& Runge 1993). Although the core habitats of $C$. finmarchicus are oceanic gyres (e.g. Jaschnov 1970, Aksnes \& Blindheim 1996), time series relating the spawning to seasonal cycles of primary productivity are still lacking from such sites.

Egg production prior to the phytoplankton bloom has been confirmed by measurements of pre-bloom egg production rates in Calanus glacialis. Under ice, in the Gulf of St. Lawrence, Canada, egg production was fuelled by feeding on ice algae before the phytoplankton bloom (Tourangeau \& Runge 1991). Smith (1990) suggested that the population of $C$. glacialis in the Fram Strait depended on reproduction prior to the bloom using lipids stored the previous feeding season. However, egg production rates measured in this region and in the Barents Sea prior to the bloom were low (Hirche \& Kattner 1993), and the significance of prebloom reproduction to the recruitment of $C$. glacialis is questionable.

Time series relating rate of egg production of Calanus glacialis to phytoplankton bloom development are rare. The complex nature of the bloom which follows the retreating ice edge, and the climatically harsh and difficult conditions for sampling in periodically ice covered oceanic regions, being the centre of the C. glacialis distribution (Conover 1988, Hirche 1991), are obvious reasons for this (Hirche \& Bohrer 1987, Hirche \& Kwasniewski 1997). A notable exception is the time series obtained at a fixed geographic location from a coastal site in Hudson Bay measuring egg production of $C$. glacialis from before the break up of the ice to the start of the phytoplankton bloom (Tourangeau \& Runge 1991). There is a strong need for complete oceanic time series relating spawning of $C$. glacialis to the dynamics of ice edge blooms.

The main reproductive period of Calanus hyperboreus usually occurs in winter, well before the phyto- plankton spring bloom, and is dependent on internally stored lipids (Sømme 1934, Wiborg 1954, Østvedt 1955, Conover 1967, 1988, Matthews et al. 1978, Smith 1990, Conover \& Siferd 1993, Hirche \& Niehoff 1996).

Calanus finmarchicus typically has a 1 yr life cycle in the Norwegian and Barents Seas (Østvedt 1955, Tande et al. 1985). For C. glacialis both 1 and 2 yr life cycles have been proposed, possibly due to geographical variations (MacLellan 1967, Tande et al. 1985, Conover \& Siferd 1993). Life cycle lengths of C. hyperboreus range from 1 yr in the Norwegian Sea and in Norwegian fjords to at least $4 \mathrm{yr}$ in the Greenland Sea and the Arctic Ocean (Sømme 1934, Wiborg 1954, Østvedt 1955, Johnson 1963, Dawson 1978, Matthews et al. 1978, Rudyakov 1983, Conover 1988, Conover \& Siferd 1993. Hirche 1997).

In the Arctic regions of the Barents Sea, covered by ice during winter, the phytoplankton spring bloom starts relatively early when the water column is stabilised by less saline surface water from the melting ice. In Atlantic water the bloom is later due to the slower process of water column stabilisation by formation of a thermocline (Rey \& Loeng 1985, Skjoldal \& Rey 1989). Lately, the view that the bloom is initiated by thermocline formation (cf. Sverdrup 1953) has been challenged, and it has been suggested that blooms take place in homogeneous water columns, initiated by the rapid increase of incident light after vernal equinox north of the Polar circle (Eilertsen et aI. 1989, 1995, Townsend et al. 1992, Eilertsen 1993). The physical conditions facilitating phytoplankton blooms and their timing in the water masses of the Barents Sea are important to the understanding and quantification of secondary production since the timing and magnitude of egg production in Calanus finmarchicus and $C$. glacialis are probably determined by the phytoplankton bloom dynamics.

Our main objectives are: (1) To examine the relationships between physical conditions, phytoplankton bloom development and egg production rates of Calanus finmarchicus and C. glacialis in Atlantic and Polar front water masses. Our hypothesis is that stabilisation of the water column is a prerequisite for the phytoplankton bloom to take place and thus the start of Calanus spp. reproduction. (2) To find life cycle lengths of $C$. finmarchicus and $C$. glacialis in the Barents Sea, and possible causes of expatriation of $C$. finmarchicus in the Arctic. Abundances of C. finmarchicus and $C$. glacialis are low in Arctic and Atlantic water, respectively, suggesting that mechanisms of expatriation are strong across the Polar front. Our hypothesis is that inability to spawn during the bloom and reduced rate of development at low temperatures are factors that make $C$. finmarchicus an expatriate in Arctic water masses. 


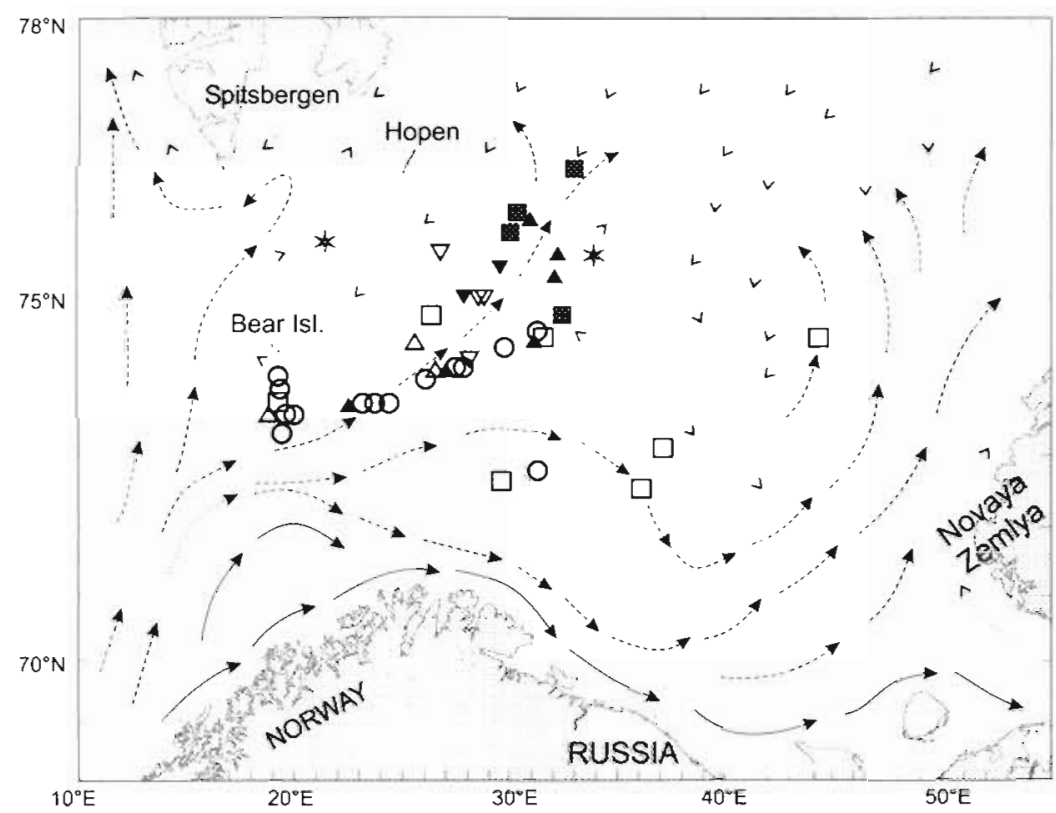

Fig. 1. Sampling stations and main features of the surface current system of the Barents Sea after Loeng (1991). Coastal currents (solid lines), Atlantic currents (dashed lines), Arctic currents (dotted lines). Sampling station symbols: (*) Arctic water early bloom; $(O)$ Atlantic water pre-bloom; $(\Delta)$ Atlantic water early

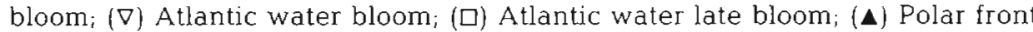
region early bloom; ( $\mathbf{v})$ Polar front region bloom; ( $\boldsymbol{\square})$ Polar front region late bloom

\section{MATERIAL AND METHODS}

Field sampling. Eight cruises during the years 1986 to 1988 covered different water masses and phytoplankton bloom situations from February to July in the Barents Sea (Fig. 1, Table 1). Two cruises in April 1986 were carried out with ice going vessels from the Norwegian Coast Guard; the other cruises were limited to the open sea. At all stations samples of eggs, nauplii and copepodite stages of Calanus spp., chlorophyll a, nutrients and hydrography were obtained.

Eggs and nauplii were sampled with 30 l Niskin water bottles, usually at 8 depths from the surface to 100 or $150 \mathrm{~m}$. The samples were sieved on $30 \mu \mathrm{m}$ (1986) or $90 \mu \mathrm{m}$ nets. During the cruises with MV 'Endre Dyrøy' eggs and nauplii were sampled with a Juday net, which had a $36 \mathrm{~cm}$ opening and a $90 \mu \mathrm{m}$ mesh size. The net was hauled vertically from $150 \mathrm{~m}$ (or the bottom) to the surface. Whether catch efficiency due to avoidance and clogging differed between the net and the water bottles is not known. However, the net samples used in the present investigation were obtained during pre-and early bloom situations, when the abundance of algae was low, and therefore clogging of the net was probably a minor problem. Copepodites of Calanus were collected with a submersible pump (Solemdal \& Ellertsen 1984), as described in Melle \& Skjoldal (1989), or with a WP-2 net, which had a $52 \mathrm{~cm}$ opening and a $180 \mu \mathrm{m}$ mesh size. The net was towed vertically from $200 \mathrm{~m}$ (or the bottom) to the surface. Zooplankton was fixed in sea water with $4 \%$ formaldehyde.

Sampling procedures for hydrography and chlorophyll a were as given by Melle \& Skjoldal (1989). Nutrients were usually taken from the entire water column, at intervals of 10 or $20 \mathrm{~m}$ down to $50 \mathrm{~m}, 25 \mathrm{~m}$ between 50 and $100 \mathrm{~m}$, and 25 or $50 \mathrm{~m}$ below $100 \mathrm{~m}$.

Laboratory and data analyses. Formaldehyde fixed zooplankton samples were sorted and counted under a stereo microscope using body size to identify all developmental stages of the Calanus species. Details on size distributions and methods of species identification from overlapping size distributions are given in Melle (unpubl.). Some morphological characteristics in addition to size were used in identifying eggs and nauplii. Eggs of C. glacialis were recognised by their spiny outer membrane. Eggs of $C$. hyperboreus were pink when alive and became black after fixation (Melle unpubl. obs.). This was probably related to the high fat content of the eggs (Conover \& Siferd 1993). Co-occurring in the sea with these eggs were relatively large (Melle unpubl.) and similarly coloured nauplii in the nauplius stages 1 to 3 (NI to NIII). We assumed these to be nauplii of $C$. hyperboreus also supplied with a large fat reserve. The nauplii of $C$. glacialis and $C$. hyperboreus could not be identified from size alone because in the nauplius stages a higher degree of size overlap is found between these 2 species than between $C$. finmarchicus and C. glacialis (Melle unpubl.).

Table 1 Cruises and sampling periods for data used in this study

\begin{tabular}{|llc|}
\hline Ship & Sampling period & $\begin{array}{c}\text { No. of sampling } \\
\text { stations }\end{array}$ \\
\hline CV 'Senja' & 5 April-11 April 1986 & 4 \\
CV 'Andenes' & 15 April-22 April 1986 & 8 \\
MV 'Endre Dyroy' & 1 February-28 April 1987 & 18 \\
(4 cruises) & & 7 \\
RV 'G.O. Sars' & 19 May-8 June 1987 & 7 \\
RV 'G.O. Sars' & 9 July-22 July 1988 & 9 \\
& & \\
\end{tabular}


Table 2. Cephalothorax length (mm) limits for distinguishing between Calanus finmarchicus, C. glacialis and C. hyperboreus in copepodite stages $\mathrm{CI}$ and $\mathrm{CII}$

\begin{tabular}{|lccc|}
\hline Stage & C. finmarchicus & C. glacialis & C. hyperboreus \\
\hline $\mathrm{CI}$ & $<0.84$ & $0.84-1.22$ & $>1.22$ \\
$\mathrm{CII}$ & $<1.22$ & $1.22-1.62$ & $>1.62$ \\
\hline
\end{tabular}

Copepodite stages 3 to 6 (CIII to CVI) were identified to species according to cephalothorax length using size limits obtained in the Barents Sea (Tande et al. 1985 Hassel 1986]. Species specific size limits for Calanus finmarchicus, C. glacialis and C. hyperboreus in CI and CII were established during this study (Table 2).

Egg size was measured as diameter, NI and NII were measured as total body length, NIII to NVI as length of carapace and copepodites as length of cephalothorax. Eggs and nauplii were measured at $100 \times$ magnification and copepodites at $25 \times$ magnification. All eggs and nauplii in the water bottles were measured except when the total number of one stage exceeded 100 specimens. In such cases a subsample of about 50 specimens was measured, but all specimens were always counted. CI and CII were measured to establish size limits between species (Table 2). Otherwise copepodites were measured only when this was necessary for allocation of specimens to the correct size group.

Egg production rates of Calanus finmarchicus and $C$. glacialis were calculated as the ratio between numbers of eggs and females in the water column at each station; this is termed the egg ratio method, a method most appropriately used to measure egg production in egg carrying zooplankton (Edmondson 1960), but also used on broadcast spawners (Sømme 1934, Tourangeau \& Runge 1991). The ratio was normalised to eggs female ${ }^{-1}$ $\mathrm{d}^{-1}$ using temperature dependent embryonic duration (Corkett et al. 1986). When losses due to egg mortality and sinking of the eggs (Melle \& Skjoldal 1989) are not accounted for, the egg ratio method applied to broadcast spawners will tend to underestimate the population egg production rate (but see 'Discussion')

An index of the ratio between abundances of copepodite stages [(CVI females $-\mathrm{CV}) /(\mathrm{CVI}$ females $+\mathrm{CV})$; Diel \& Tande 1992] was calculated to describe the state of development in the overwintered populations and to see if the spawning event led to changes in the female population that was traceable in the copepodite stage ratio.

Samples for chlorophyll a were stored and analysed as described by Rey \& Loeng (1985). Nutrients (nitrite, nitrate, phosphate, silicate) were usually analysed onboard using an 'automated sampling system' as described by Foyn et al. (1981). On the cruises with
MV 'Endre Dyrøy' the nutrient samples were preserved by adding chloroform and kept in the dark in a refrigerator until they were analysed shortly after the cruise (Hagebo \& Rey 1984). In the present investigation only nitrate data are used.

The consumption of nitrate in the water column gives a cumulative measure of the development of the phytoplankton spring bloom, at least during the early phases of the bloom when remineralisation is low. Amount of nitrate consumed was estimated as the difference between integrated nitrate concentrations in the upper $100 \mathrm{~m}$ and assumed amounts of nitrate over the same depth during winter $\left(\mathrm{mmol} \mathrm{m}^{-2}\right)$, taken as nitrate concentrations at $100 \mathrm{~m}$. Chlorophyll concentrations were integrated over the upper $100 \mathrm{~m}$ to represent the water column chlorophyll content $\left(\mathrm{mg} \mathrm{m}^{-2}\right)$.

Two different measures of water column stability were derived: $\Delta \sigma_{t}$, which is the difference in water density between 5 and $100 \mathrm{~m}$ depth in $\sigma_{\mathrm{t}}$ units, and $\Delta T$ $\left({ }^{\circ} \mathrm{C}\right)$, which is the maximum change in temperature over every $5 \mathrm{~m}$ depth interval in the water column. Temperature was used instead of density because salinity data were missing at some stations and because stabilisation in the Atlantic water mass is mainly related to the formation of a thermocline (e.g. Rey \& Loeng 1985).

The sampling stations were grouped into hydrographic regions and within hydrographic regions into state of phytoplankton bloom development. Using characteristic temperatures and salinities as given by Loeng (1991) and Hassel et al. (1991), sampling stations were classified as belonging to Atlantic water, the Polar front region or Arctic water. Since only 2 truly Arctic stations were available, these data were not included in further analyses except egg production rates given in Table 4 . The Polar front region, as defined here, is not a water mass but a region where Atlantic and Arctic water masses are mixed and transformed as described by Loeng (1991). A common feature of the stations from the Polar front region was the layer of low salinity melt-water from melting ice topping the water column during spring and summer. Stations with melt-water on top of Atlantic water were also put in this category.

Phytoplankton spring bloom development was separated into 4 phases: pre-bloom, early bloom, bloom and late bloom. The classification was based on vertical profiles of hydrography, nitrate and chlorophyll concentrations. These data are not shown here. The prebloom situation was characterised by low water column stability, low chlorophyll concentrations $(<0.5 \mu \mathrm{g}$ $\left.\mathrm{l}^{-1}\right)$ and winter concentrations of nitrate (10 to $\left.13 \mu \mathrm{M}\right)$ in the water column. The early bloom situation was characterised by weak stratification, low chlorophyll concentrations $\left(<2 \mu \mathrm{g} \mathrm{l}^{-1}\right)$ and high nitrate concentrations $(>5 \mu \mathrm{M})$ in the water column. The bloom situation 
Fig. 2. Phytoplankton development in Atlantic water. Integrated chlorophyll content (0 to $100 \mathrm{~m}$ ), nitrate consumption (difference between integrated nitrate concentrations and assumed winter concentrations) and $\Delta \sigma_{t}$ (difference in water density between 5 and $100 \mathrm{~m}$ depth) vs time (Julian day and months). Open symbols: 1987; filled symbols in April: 1986; filled symbols in July: 1988

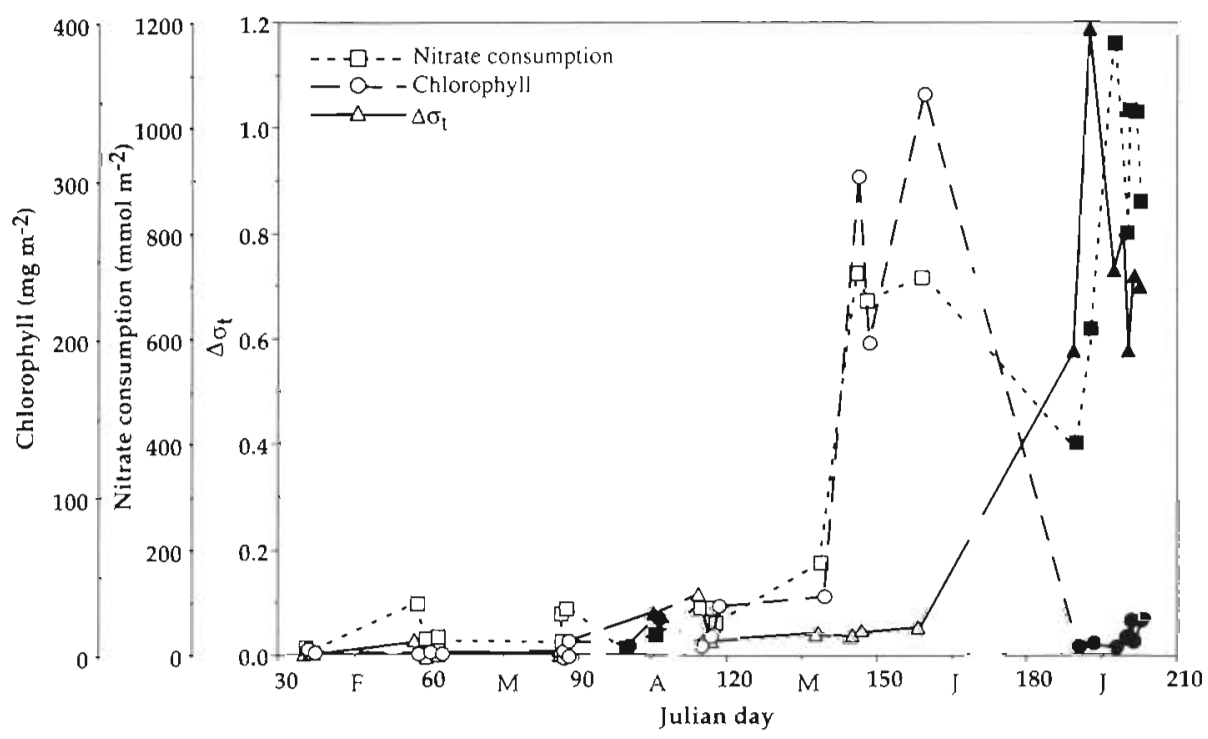

was characterised by some stratification, high chlorophyll concentrations $\left(>2 \mu \mathrm{gl}^{-1}\right)$ and low nitrate concentrations $(<2 \mu \mathrm{M})$ in the mixed layer. The late bloom situation was characterised by strong stratification, low nitrate concentrations in the mixed layer $(<0.5 \mu \mathrm{M})$ and a deep chlorophyll maximum $\left(>1 \mu \mathrm{g} \mathrm{l}^{-1}\right)$ within or just below the pycnocline.

\section{RESULTS}

\section{Atlantic water}

\section{Phytoplankton bloom development}

Spring phytoplankton bloom development in Atlantic water was described by combining the stations sampled from early February to late July in 1986, 1987, and 1988 on a single time axis (Fig. 2). In late April and in the middle of May 1987 small amounts of chlorophyll and some consumption of nitrate in the water column indicated that phytoplankton growth had started. Bloom development at stations sampled in April 1986 did not deviate from that at stations in April 1987. Some time during the last half of May bloom development accelerated, as evident from the large amounts of nitrate consumed and the high chlorophyll content in late May and early June (Fig. 2). The limited number of stations available from Atlantic water in May prohibited a more accurate dating of the initiation of the bloom. In July 1988 the amount of chlorophyll in the water column was low and the bloom was over. The amount of nitrate consumed and the index of water column stability, $\Delta \sigma_{1}$, were both high (Fig. 2).

The high water column stability that occurred at the late bloom stations in July showed that strong stabili- sation of the water column was related to the culmination rather than the initiation of the bloom (Fig. 2). However, the phytoplankton bloom was initiated before the major increase in the index of water column stability, $\Delta \sigma_{t}$. Therefore, $\Delta T$, which, supposedly, better reflects the small changes in density in the thermocline, was introduced as an alternative measure of stability. After $\log$-log transformation the nitrate consumption showed a significant linear relationship with $\Delta T$, indicating that the initiation of the bloom is associated with a weak stabilisation (Fig. 3). When the bloom stations were excluded from the analysis the relationship was still significant (Fig. 3).

Egg production and stage distribution of Calanus spp.

Variations in rate of egg production (eggs female ${ }^{-1}$ $\mathrm{d}^{-1}$ ) of Calanus finmarchicus were closely related to integrated water column chlorophyll content (Fig. 4). The index of the stage ratio between number of CVI females and $\mathrm{CV}$ of $C$. finmarchicus increased from only $\mathrm{CV}(-1)$ in February to almost exclusively adult females (1) in early May (Fig. 4). The most distinct drop in the stage ratio index coincided with the highest rate of egg production, and in July the index was mostly below -0.75 , which is more than $87 \% \mathrm{CV}$ (Fig. 4).

A general decrease in the abundance of $\mathrm{CV}$ of the overwintered generation from February to June reflected the moulting into adults (Fig. 5). After the strong increase of egg production in late May, a reduction in the abundance of females relative to $\mathrm{CV}$ followed, as seen in the decrease of the stage ratio index in Fig. 4 . The reduction in the stage ratio index was probably not related to the recruitment of $\mathrm{CV}$ from the new generation as this generation had only reached CIII at the stations in May 


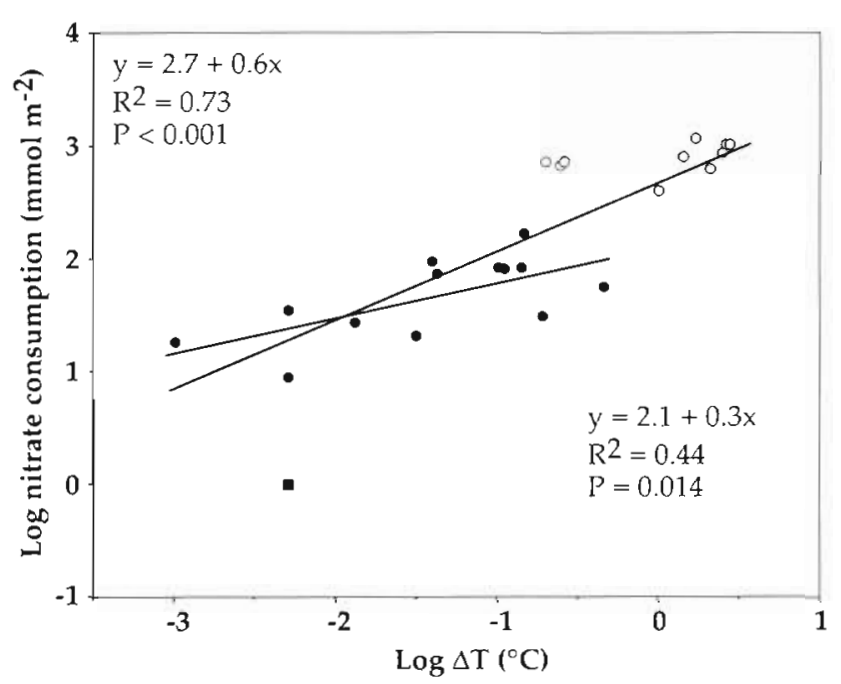

Fig. 3. Relationship between phytoplankton bloom development expressed as depth integrated nitrate consumption 10 to $100 \mathrm{~m}$ ) and thermocline formation, $\Delta T$, expressed as the strongest temperature differences over $5 \mathrm{~m}$ in the water column. Upper equation and statistics refer to the regression of the total data set, the lower refer to the regression of the prebloom and early bloom stations ( excluding the bloom and late bloom stations (O). One station ( $\square$ ) was defined as an outlier and not included in the regressions

and early June (Fig. 5). Hardly any adult males were found during the sampling period, which may have been related to shorter life span duration of the males, but also to the limited sampling depths during the winter and early spring $(200 \mathrm{~m})$ and the general tendency of Calanus finmarchicus to mate in deeper waters (Conover 1988, Miller et al. 1991). Adult males during summer, indicative of a second spawning, were only observed at the last and southernmost sampling station (day number 202, Fig. 5). The very few adult females still spawning in July probably were remnants of the overwintered generation.

The new generation of Calanus finmarchicus first occurred in low numbers as eggs and young nauplius stages in late March and early April (Fig. 5). These were recruits from the low pre- and early bloom spawning (this may not be visible in Fig. 4, but see Table 4 in which averaged egg production rates for the pre- and early bloom phases are shown). The abundances of eggs and nauplii peaked in late May and early June when the chlorophyll content peaked. Generally low numbers of nauplii were found in July except on day 200 at the easternmost station (Fig. 5). Copepodites in high numbers were first encountered in the beginning of June and mainly as CI and CII. The first CIV made considerable contributions to the population in July. However, we had no samples from mid and late June. The high abundances of CV in July most likely represented the new generation. C. finmarchicus seemed to have a 1 yr life cycle in Atlantic water.

The pattern of spawning in Calanus glacialis resembled that of $C$. finmarchicus. Egg production was low during the pre- and early bloom periods, high but variable during the bloom period, and low again during the late bloom period (Fig. 6, see also Table 4). The copepodite stage ratio index dropped at the start of, or just before, the period of high egg production in May. The fall in the ratio when the spawning at a high rate started could have been due to reduced numbers of CVI females, but also development of overwintered CIV into CV. In contrast to C. finmarchicus, there were no CV of C. glacialis from February to April (stage ratio index $=1.0$ ). Stage distribution after wintering was bimodal and consisted of CIII, CIV and CVI (Fig. 7). CIV seemed to be a resting stage during wintering

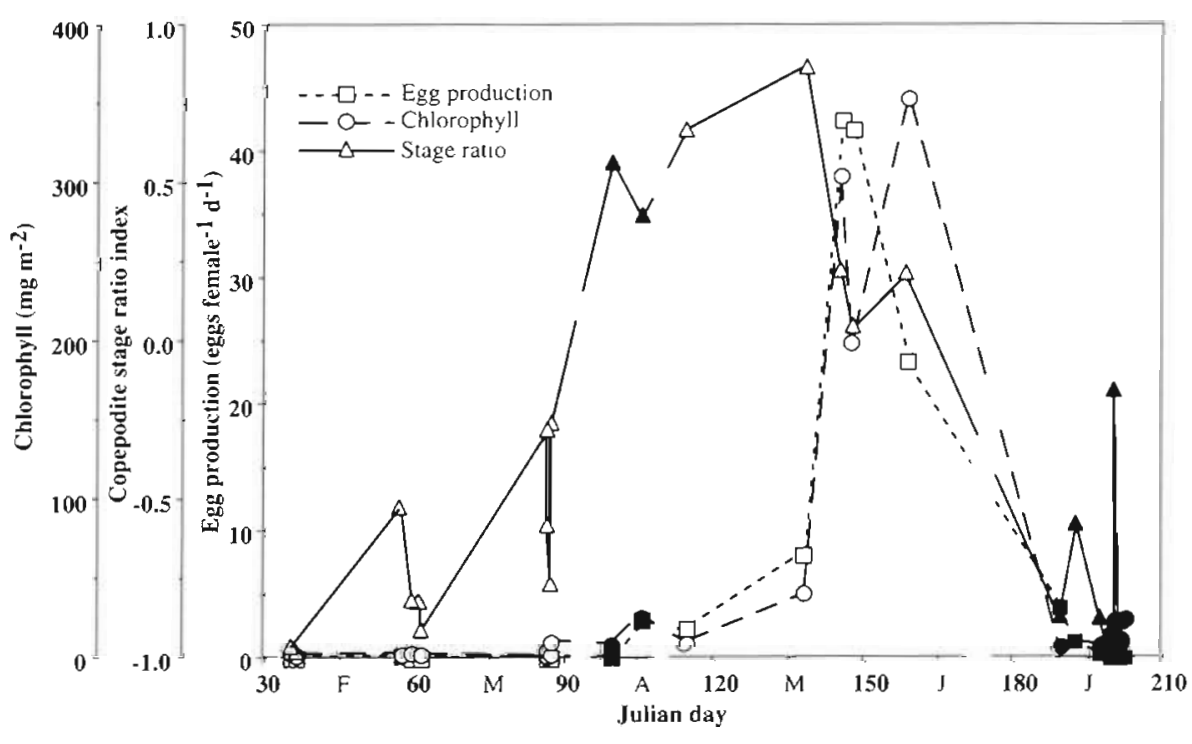

Fig. 4. Egg production of Calanus finmarchicus and copepodite stage ratio index and depth integrated chlorophyll content (0 to $100 \mathrm{~m}$ ) vs time (Julian day and months) in Atlantic water. Open and filled symbols as in Fig. 2 


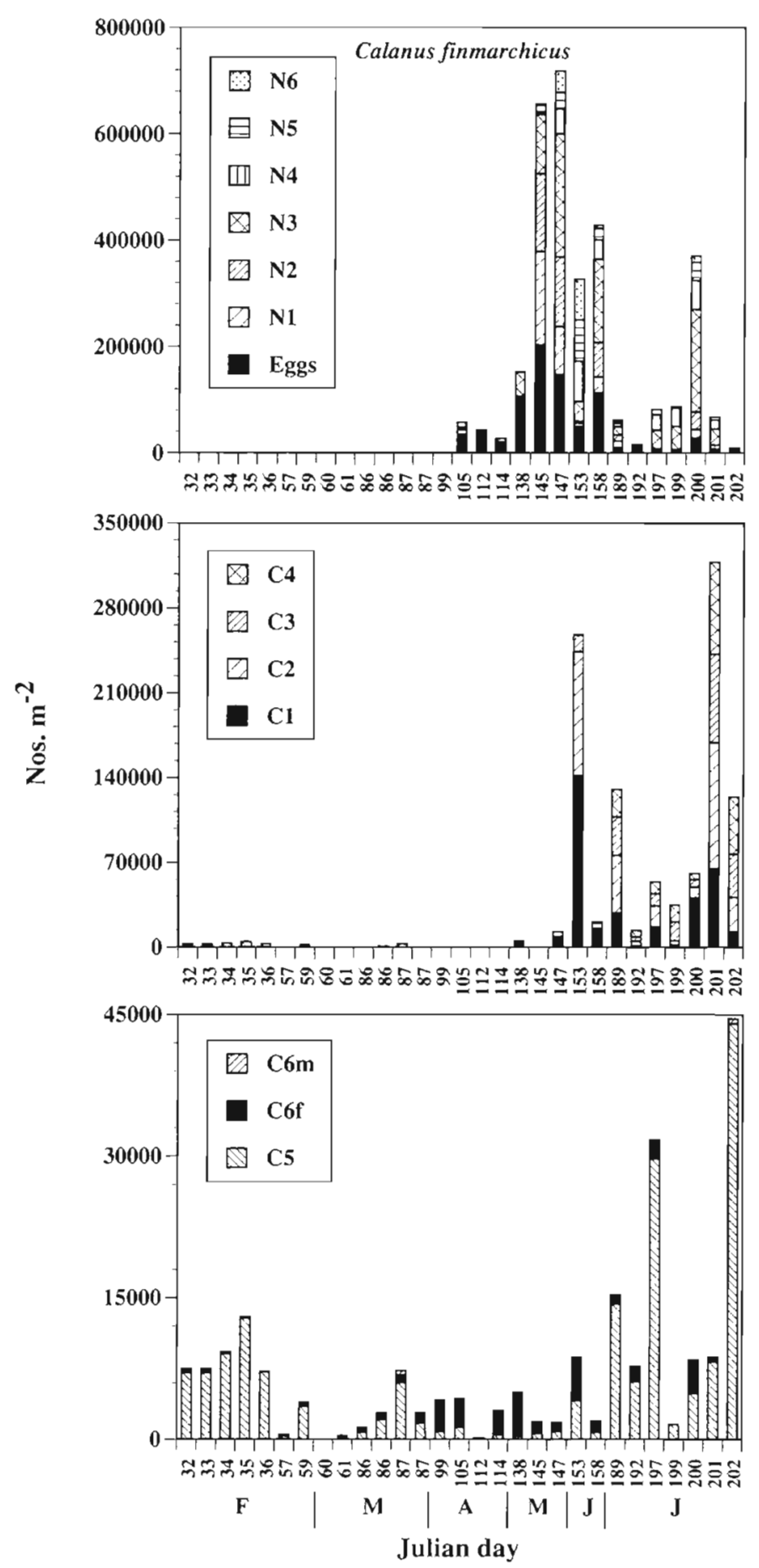

Fig. 5. Calanus finmarchicus. Abundance of eggs, nauplii and copepodites vs time (Julian day and months) in Atlantic water. Note that the time axis is not linear

which may indicate that some individuals had a life cycle of more than a year.

In February and March the eggs of Calanus hyperboreus were more abundant than the eggs of $C$. glacialis (Figs. 7 \& 8). From February to April most Calanus nauplii of the largest size fraction, which could in principle be of both C. glacialis and C. hyperboreus, were rich in fat like the eggs of $C$. hyperboreus (see 'Material and methods'). We therefore assume that the nauplii occurring from February to April were mainly C. hyperboreus. After April the fraction of fatty nauplii was lower, the abundance of eggs of $C$. glacialis was higher relative to C. hyperboreus, and CI and CII in May and June were mainly C. glacialis. Therefore the largest Calanus nauplii in May and June presumably were mainly C. glacialis. Due to the equivocal species identification, however, all Calanus nauplii belonging to the large size fraction are included in both Fig. 7 and Fig. 8.

The new generation of Calanus glacialis in Atlantic water was mainly found as eggs and nauplii during the bloom in May and as copepodites in June and July. The high numbers of CV that occurred in late June and early July could not have developed from the low numbers of CIII and CIV during spring (taking sampling over different years into consideration). Therefore a major part of the new generation seemed to reach $\mathrm{CV}$ and possibly CVI before the start of the winter, having a 1 yr life cycle.

The reproduction of Calanus hyperboreus could not be described by egg production rate and copepodite stage ratio because CV and CVI females were hardly present in Atlantic water during the sampling period. Egg abundances showed that spawning occurred throughout the sampling period from February to July (Fig. 8). Highest abundances of eggs were found during the bloom period in May and June. Even though spawning had been going on since February, and possibly earlier, no nauplii older than NIII were found until the first NIV occurred in the middle of April, at the time of the first weak increase in chlorophyll content (Figs. $2 \& 8$ ). Although the spawning started earlier, the new generation of C. hyperboreus did not seem to develop into copepodites earlier than the other 2 Calanus species (Fig. 8).

\section{Polar front region}

\section{Phytoplankton bloom development}

In the Polar front region, as opposed to Atlantic water, the phytoplankton spring bloom did not develop strictly with time. This was expected since the bloom starts when the ice melts and the water column is stabilised by the input of low salinity water from the melting sea ice. In general various stages of phytoplankton bloom succession are found along a gradient from the open sea towards the retreating ice 


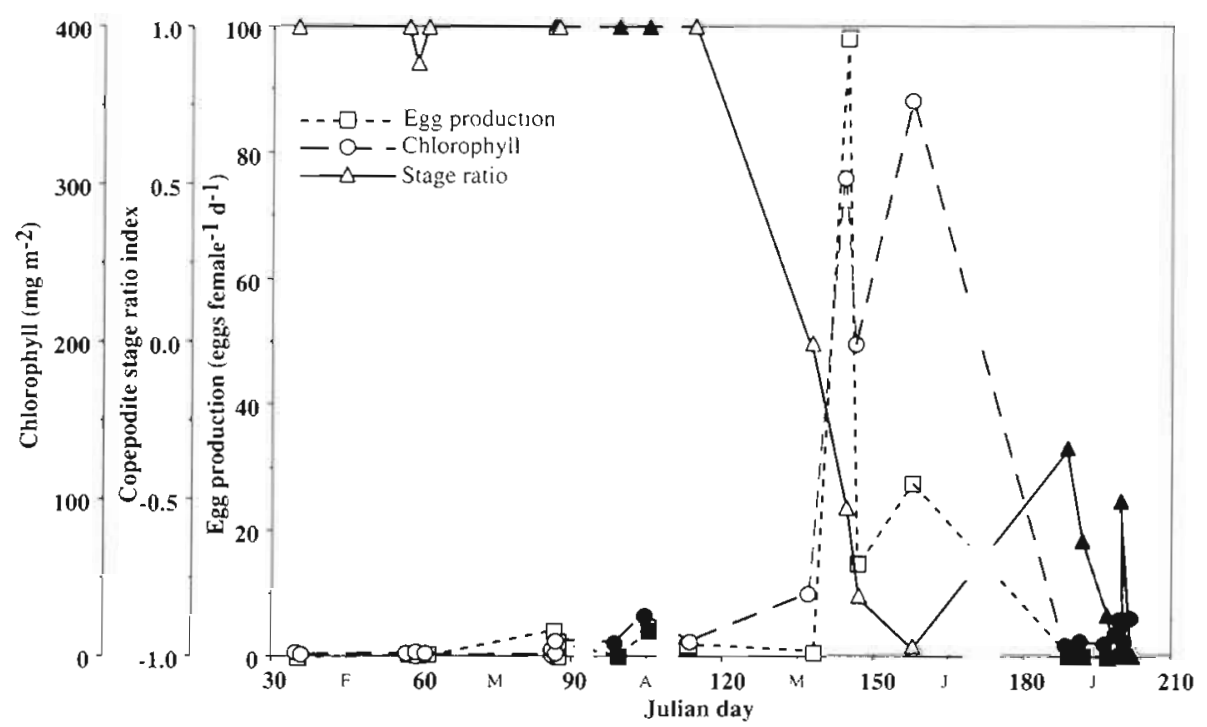

Fig. 6. Egg production of Calanus glacialis and copepodite stage ratio index and depth integrated chlorophyll content ( 0 to $100 \mathrm{~m}$ ) vs time (Julian day and months) in Atlantic water. Open and filled symbols as in Fig. 2

edge (Rey \& Loeng 1985, Skjoldal et al. 1987, Skjoldal \& Rey 1989). Therefore, areas ranging from typical pre-bloom to post-bloom situations can be observed at the same time during spring and summer in the Polar front region.

To be able to make general conclusions about spawning and development of Calanus spp. relative to bloom development, we needed a gradient other than time along which the bloom development of this region could be sequenced. Neither nitrate consumption nor water column stability alone described bloom development very well. We therefore included physical and chemical variables representing both requirements and results of the bloom in a Principal Component Analysis (PCA). Before the PCA a correlation analysis was used to remove redundant parameters from groups of highly correlated parameters, and the remaining parameters are listed in Table 3. PCA was performed on a covariance matrix in SYSTAT (Wilkinson 1992j. Prior to analysis variables were standardised to zero mean and unit variance, and $\Delta \sigma_{i}, N C O N S U$ and CHLMAX were log-transformed.

The PCA showed that the first axis was mainly a gradient of salinity, nitrate and temperature. The sample (station) scores (e.g. ter Braak \& Prentice 1988) along the first PCA axis were taken as an index of bloom development; however, due to the inclusion of both determinant and responding parameters in the analysis the axis is not considered a causal gradient.

A plot of nitrate consumption and chlorophyll content versus the first PCA axis showed that nitrate increased towards an asymptote and that chlorophyll content increased to a maximum and thereafter decreased to low values (Fig. 9), apparently describing the initiation and culmination of the ice edge bloom. As in Atlantic water the bloom was initiated before the major increase in $\Delta \sigma_{t}$. The initiation and culmination of the bloom was described by data from one year, 1986. The bloom started in April, more than a month before the bloom in Atlantic water masses (Fig. 9). Data from May 1987 and July 1988 described the late bloom period. Since the stations now seemed to be arranged along a quantitative axis of bloom development we used this sequence in the further analysis of spawning and development of Calanus spp. relative to the spring phytoplankton bloom.

Egg production and stage distribution of Calanus spp.

Rather low rates of egg production $(\sim 10$ eggs female $e^{-1} \mathrm{~d}^{-1}$ ) of Calanus finmarchicus were observed in the middle of April during the bloom (Fig. 10). Maximum spawning rate was not observed during the bloom but at a late bloom station, sampled in July 1988. Unlike the situation in Atlantic water, the stage ratio index did not reach high values before spawning (Fig. 10), and the index was rather low throughout the sampling period. This may indicate that spawning in the Polar front region starts before the major part of the $\mathrm{CV}$ has developed into CVI, and that after the start of spawning reduction in number of females prevents the ratio from building up towards 1.0 .

Eggs of Calanus finmarchicus were found at all times from April to July in the Polar front region. The first nauplii occurred in late April and the maximum numbers of eggs and nauplii were found during the late bloom period in late May and early June 1987 (Fig. 11). The new generation of copepodites (CI to CIII) occurred in high numbers at only 1 station, in July 1988, indicating late or low recruitment. The relatively high numbers of CIV and CV from the overwintered 

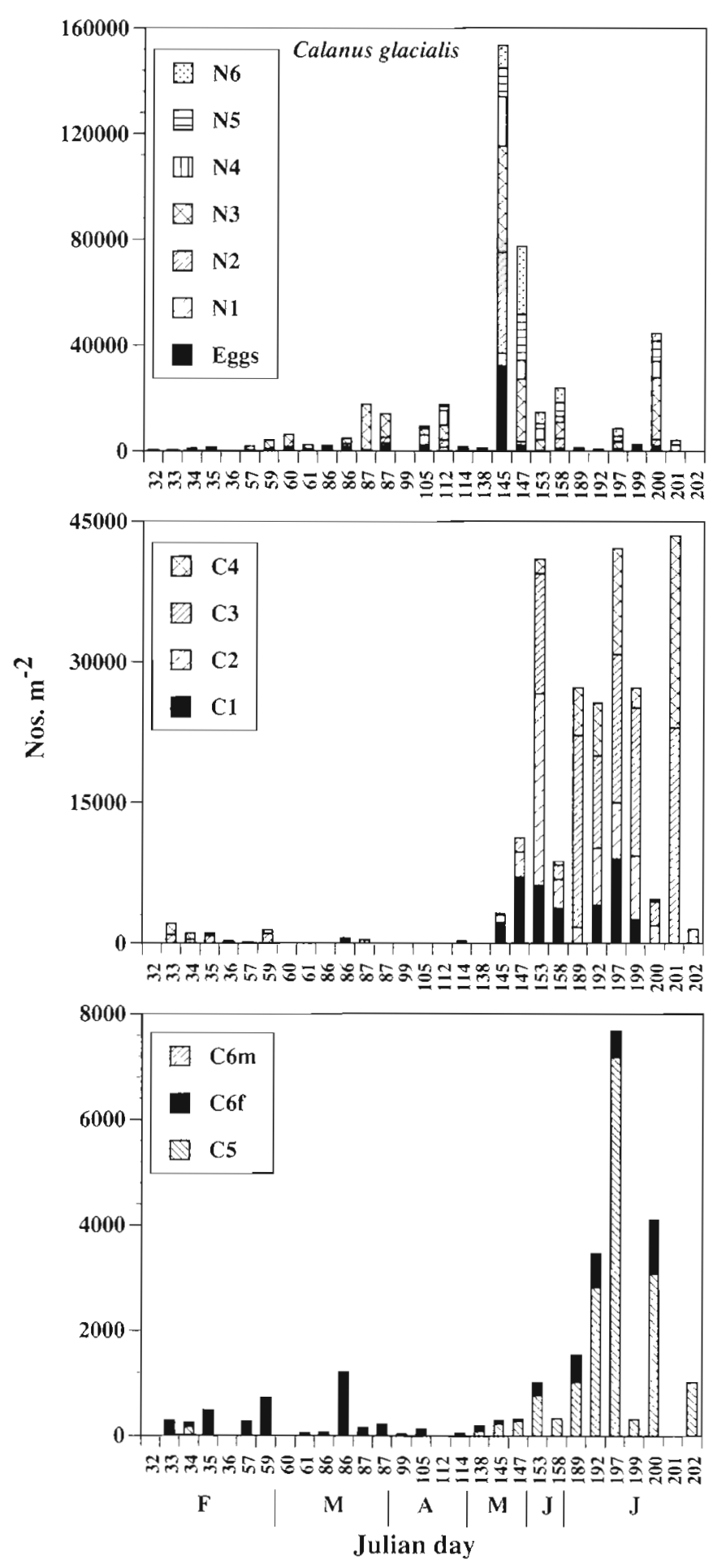

Fig. 7. Calanus glacialis. Abundance of eggs, nauplii and copepodites vs time (Julian day and months) in Atlantic water. Nauplii may be both $C$ glacialis and $C$. hyperboreus. Note that the time axis is not linear

generation together with the low stage ratio index during the early bloom and bloom periods indicated that development of the overwintered population in the
Polar front region was late compared to the population in Atlantic water (Fig. 11). Individuals emerging from the wintering as $\mathrm{CV}$ and $\mathrm{CVI}$ persisted in the population until mid July. There did not seem to be more than 1 yr class present, however, and most individuals probably had a 1 yr life cycle. It is not clear whether late spawned individuals can complete their life cycle within the next year.

The egg production rate of Calanus glacialis in the Polar front region peaked at nearly 80 eggs female ${ }^{-1}$ $\mathrm{d}^{-1}$ during the bloom in the middle of April, while the spawning rate was lower in May, June and July (Fig. 12). The stage ratio index showed that the overwintered generation about to spawn consisted of CVI females only. The low stage ratio index at late bloom stations in May-June 1987 and July 1988 may in part have been due to CIV moulting into CV.

The new generation of Calanus glacialis had developed into nauplii during the bloom in April (Fig. 11). We made no attempt to distinguish between nauplii of C. glacialis and C. hyperboreus from the Polar front region; however, the abundance of $C$. hyperboreus was much lower than of C. glacialis. Thus, most nauplii were probably $C$. glacialis. During the late bloom period in May, June and July the new generation occurred as late nauplius stages and as copepodite stages CI, CII and CIII (Fig. 11).

Stage distribution of the overwintered population of Calanus glacialis was bimodal (CIII, CIV and CVI). CIII and CIV seemed to start developing into $\mathrm{CV}$ in May after the culmination of the bloom, and until then no $\mathrm{CV}$ were present. The last overwintered individuals of CIII developed into CIV at that time. Adult females seemed to persist through the bloom and late bloom phase and disappeared at the most advanced station in July probably after spawning (Fig. 11). It is not clear whether all of these females had overwintered twice or if some of them were late spawners developing from the overwintered CIII and CIV. Many CV among the high numbers occurring in June and July most likely were spawned the same spring, thus approaching a 1 yr life cycle. The relatively high numbers of CIII and CIV in late May that already had overwintered once indicated that a higher proportion of the CV in late summer had developed from these. Thus, individuals with 1 and 2 yr life cycles seemed to co-exist in the Polar front region. Still, the fraction with a 2 yr life cycle was higher here than in Atlantic water.

\section{DISCUSSION}

We were not able to obtain complete time series describing seasonal cycles of phytoplankton bloom 

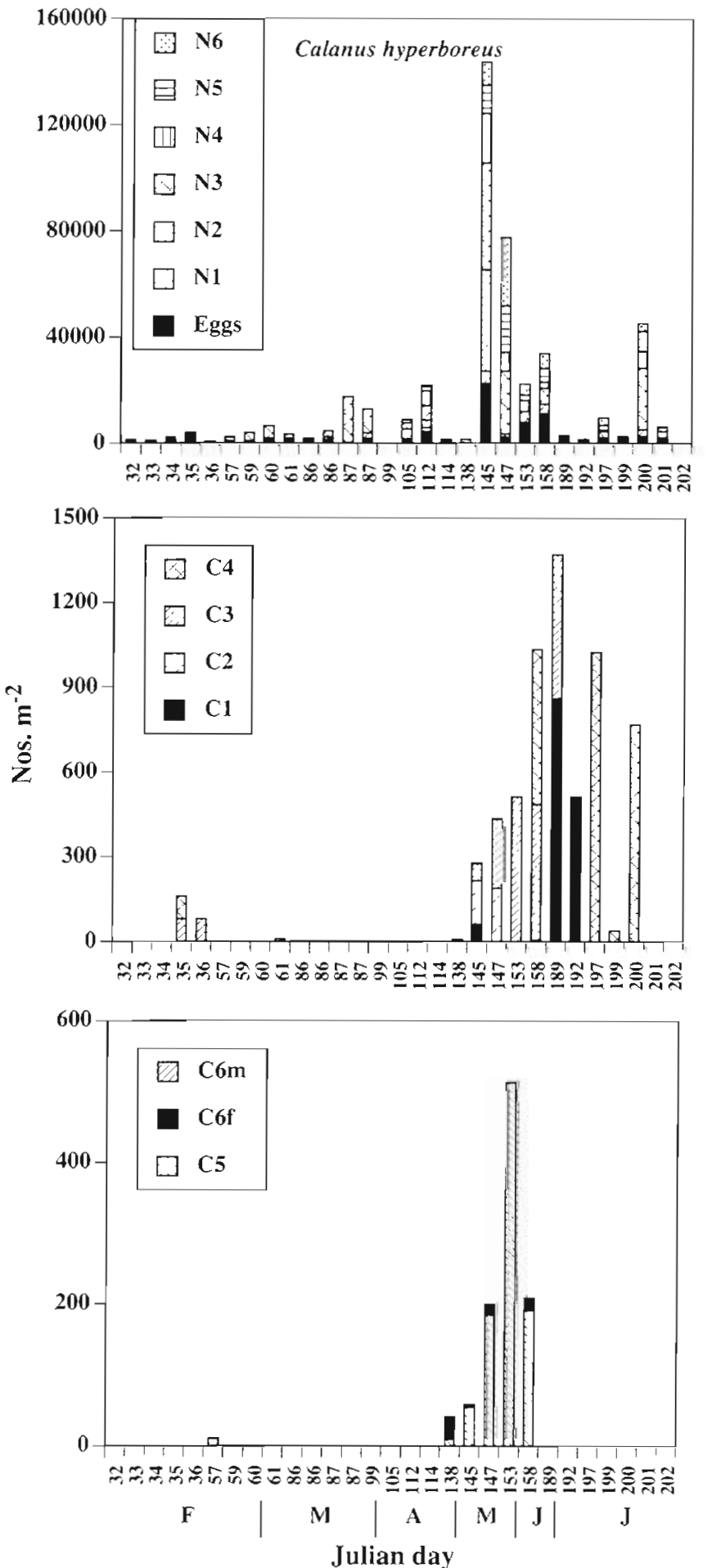

Fig. 8. Calanus hyperboreus. Abundance of eggs, nauplii and copepodites vs time (Julian day and months) in Atlantic water. Nauplii may be both $C$. glacialis and C. hyperboreus. Note that the time axis is not linear

development and Calanus spp. reproduction from a single year in any water mass. Still, our time series from Atlantic water in 1987 and the Polar front region in 1986 (Table 1) covered the shift from the pre- or low reproductive to the reproductive phase of $C$. finmarchicus and C. glacialis, and the initiation of the phytoplankton bloom. Thus, our data could be used for relating reproduction of Calanus spp. to phytoplankton spring bloom development based on time series from oceanic sites.

Time series of biological parameters in marine zooplankton populations are influenced by advection. The relationship between advective and biological processes influencing time series of ocean studies of Calanus finmarchicus has been analysed by Aksnes \& Blindheim (1996). We classified our sampling stations according to water masses and our main focus was changes in egg production rates. Biological processes may be homogeneous within water masses and egg production rate is characterised by rapid changes; thus, our results may reflect biological processes more than advection.

\section{Phytoplankton spring bloom development}

The initiation of the phytoplankton spring bloom in Atlantic water coincided with the first water column stabilisation (Fig. 3). Except for episodic phytoplankton growth under extremely calm conditions (e.g. Halldal 1953, Sverdrup 1953) and blooms in shallow shelf regions where bottom depth is less than the critical depth (Sverdrup 1953), stabilisation of the water column is generally a prerequisite for the initiation of a phytoplankton bloom (Sverdrup 1953). Our results obtained at deep water locations agree well with the classical theory of water column stabilisation and initiation of phytoplankton spring blooms (Sverdrup 1953, Sambrotto et al. 1986) and contradict more recent reports that phytoplankton blooms are initiated in homogeneous water columns controlled by the rapidly changing light conditions of northern regions (Eilertsen et al. 1989, 1995. Townsend et al. 1992, Eilertsen 1993). Whether the very weak thermoclines observed in the present investigation are enough to initiate the phytoplankton bloom calls for further experiments. At present, however, we conclude that the initiation of phytoplankton blooms in Atlantic water depends on water column stratification.

The largest difference in stability of the water column in Atlantic water was observed between bloom stations in June (1987) and late bloom stations in July (1988). Thus, culmination of the bloom occurred after strong stratification of the water column.

In the Polar front region the layer of less saline meltwater on top of Atlantic water stabilised the water column in April, causing initiation and culmination of a phytoplankton bloom as described by Rey \& Loeng 
Table 3. Parameters included in ordination (Principal Component Analysis) of sampling stations representing phytoplankton spring bloom development in the Polar front region

\begin{tabular}{|ll|}
\hline Parameter & \multicolumn{1}{c}{ Description } \\
\hline MAXPDT & $\begin{array}{l}\text { Depth of pycnocline. Defined as depth of maximum change of water density over a } 5 \mathrm{~m} \text { interval within } \\
\text { the water column }(\mathrm{m})\end{array}$ \\
$\Delta \sigma_{1}$ & Difference in water density between 5 and $100 \mathrm{~m}\left(\sigma_{1}\right.$ units $)$ \\
S100 & Salinity at $100 \mathrm{~m}$ \\
T100 & Temperature at $100 \mathrm{~m}\left({ }^{\circ} \mathrm{C}\right)$ \\
NCLDT & Depth of nitracline $(\mathrm{m})$ \\
NCONSU & Nitrate consumption, see 'Material and methods' $\left(\mathrm{mmol} \mathrm{m}^{-2}\right)$ \\
CHLMAX & Maximum chlorophyll concentration in water column $\left(\mathrm{ug} \mathrm{m}^{-3}\right)$ \\
\end{tabular}

Fig. 9. Phytoplankton development in the Polar front region. Depth integrated chlorophyll content (0 to $100 \mathrm{~m})$, nitrate consumption (difference between integrated nitrate concentrations and assumed winter concentrations) and $\Delta \sigma_{t}$ (difference in water density between 5 and $100 \mathrm{~m}$. depth) vs station scores along first PCA axis (see text). Open and filled symbols as in Fig. 2. Numbers beside chlorophyll symbols are times of sampling (Julian day)

Fig. 10. Calanus finmarchicus. Egg production and copepodite stage ratio index of and depth integrated chlorophyll content 10 to $100 \mathrm{~m})$ vs station scores along first PCA axis for stations from the Polar front region. Open and filled symbols as in Fig. 2 Numbers beside chlorophyll symbols are times of sampling (Julian day)
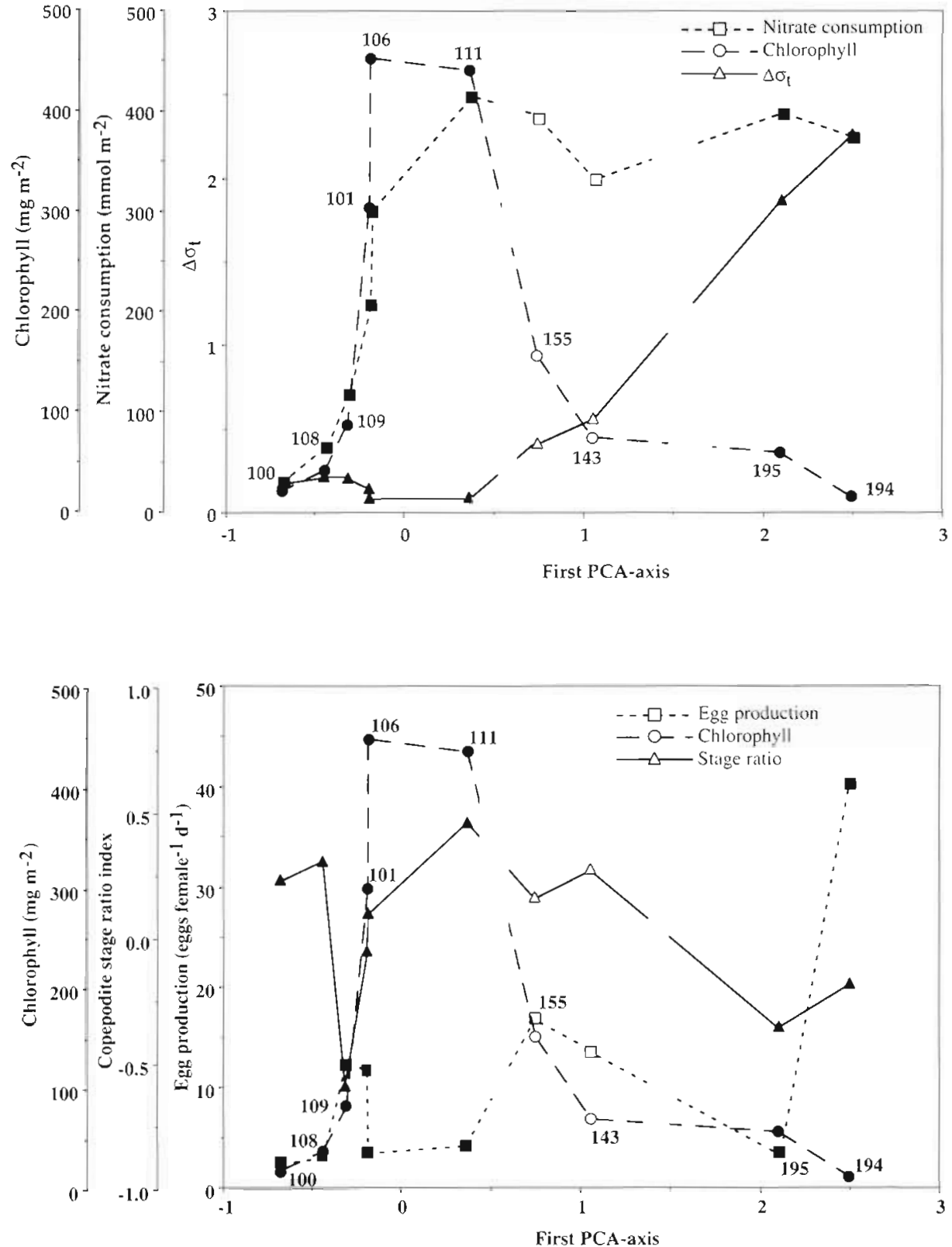

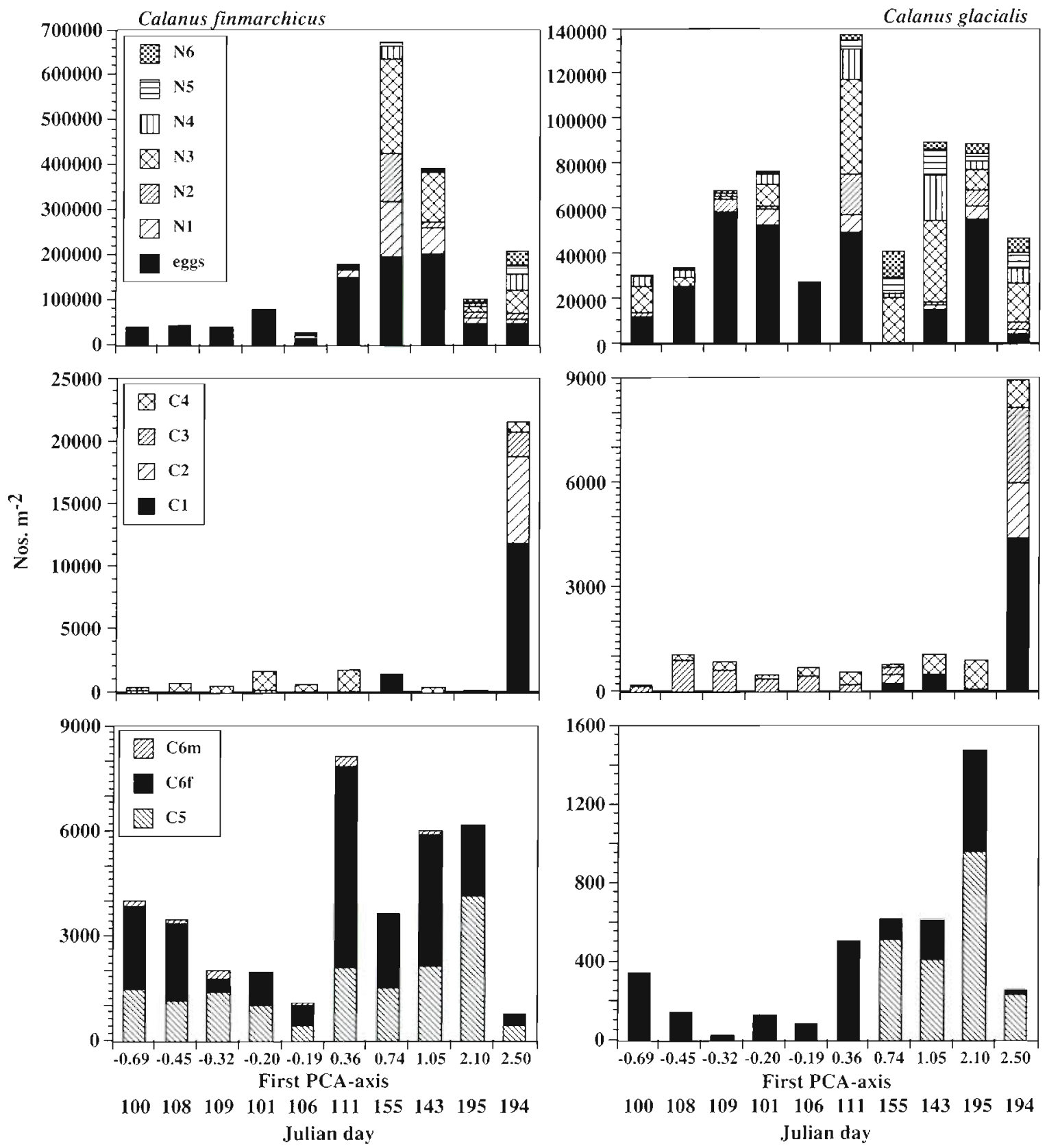

Fig. 11. Calanus finmarchicus and C. glacialis. Abundance of eggs, nauplii and copepodites vs station scores along first PCA axis and time (Julian day) for stations from the Polar front region. Nauplii in right hand panel may be both C. glacialis and $C$. hyperboreus. Note that the $x$-axis is not linear

(1985). The time for the initiation of the bloom coincided with other estimates in the Polar front region of the Barents Sea (Rey \& Loeng 1985, Skjoldal et al 1987, Sakshaug \& Skjoldal 1989, Skjoldal \& Rey 1989). The bloom in the Polar front region was initiated more than 1 mo earlier than in Atlantic water, which shows the strong effect of the melt-water on the timing of the bloom

\section{Egg production, development and life cycle of Calanus spp.}

Rates of egg production of Calanus finmarchicus and C. glacialis in different water masses and bloom conditions (Figs. 4, 6, $10 \& 12$ ) are summarised in Table 4 and compared with results of previous investigations relating rates of egg production to bloom conditions or 
Fig. 12. Calanus glacialis. Egg production and copepodite stage ratio index and depth integrated chlorophyll content (0 to $100 \mathrm{~m}$ ) vs station scores along first PCA axis for stations from the Polar front region. Open and filled symbols as in Fig. 2. Numbers beside chlorophyll symbols are times of sampling (Julian day)

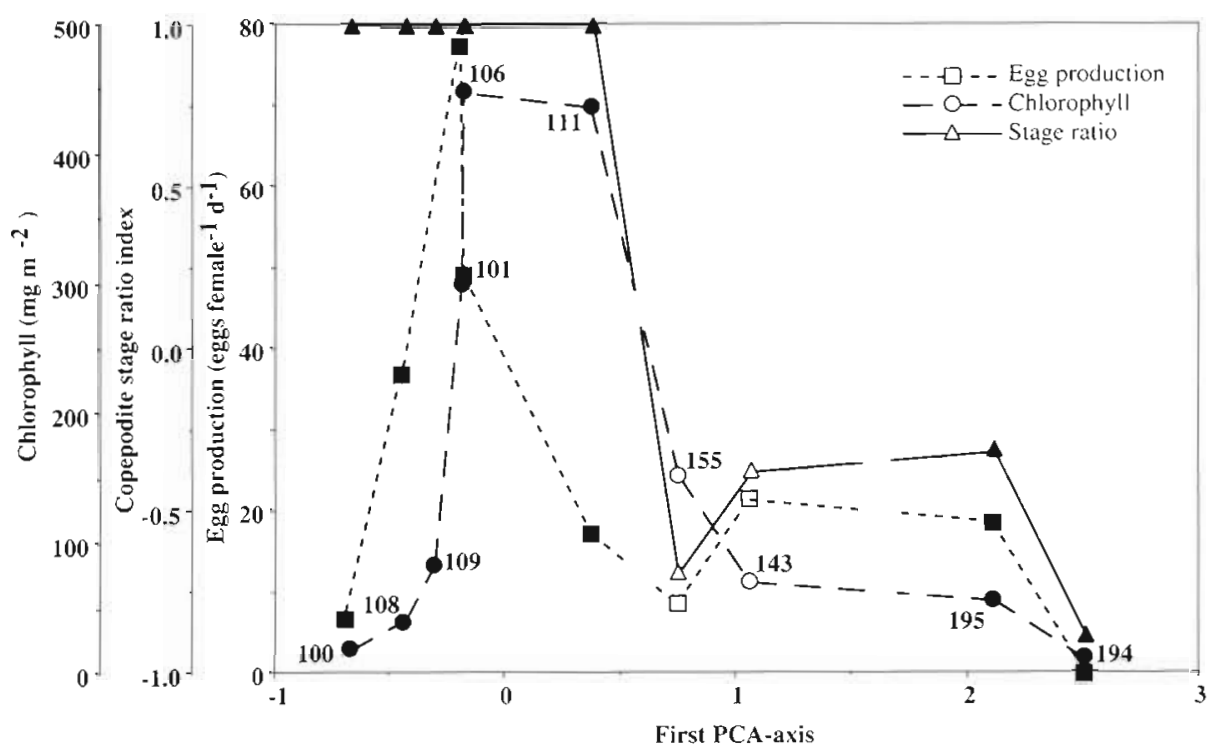

Table 4. Calanus finmarchicus and C. glacialis. Egg production rates (eggs female $\mathrm{e}^{-1} \mathrm{~d}^{-1}$ ) in relation to bloom conditions. Results related to bloom conditions defined by the authors or results obtained from time series are given in bold. Otherwise, the sites were classified by us according to the amount of chlorophyll in the water column (0 to $100 \mathrm{~m}$ ): pre-bloom $<5$, early bloom 5 to 30 , bloom $>30$, and late bloom 5 to $30 \mathrm{mg} \mathrm{chl} \mathrm{m} \mathrm{m}^{-2}$ (note that levels of chlorophyll are different from those used in the present investigation)

\begin{tabular}{|c|c|c|c|c|c|}
\hline Site & $\begin{array}{c}\text { Pre- } \\
\text { bloom }\end{array}$ & $\begin{array}{l}\text { Early } \\
\text { bloom }\end{array}$ & Bloom & $\begin{array}{l}\text { Late } \\
\text { bloom }\end{array}$ & Source \\
\hline \multicolumn{6}{|l|}{ Calanus finmarchicus } \\
\hline Nova Scotia, Canada & & 2 & 21,30 & & Runge (1985) \\
\hline Greenland Sea & $\mathbf{0}$ & & & & Smith $(1990)$ \\
\hline Norwegian coast & & $<10$ & $21-23$ & $<10$ & Diel \& Tande $(1992)^{\mathrm{a}}$ \\
\hline Barents Sea & $0^{\mathrm{b}}$ & & & & Hirche \& Kattner (1993) \\
\hline St. Lawrence Estuary, Canada & $\sim 0$ & $0-10$ & $22-82$ & $\sim 40$ & Plourde \& Runge (1993) \\
\hline Gulf of St. Lawrence & & & 21 & 26 & Ohman \& Runge 1994 \\
\hline Barents Sea Atlantic water & $0-0.2$ & $2-8$ & $24-44$ & $0.3-4$ & This study \\
\hline Barents Sea Polar front region & - & $2-12$ & $4-12$ & $4-40$ & This study \\
\hline Barents Sea Arctic water & - & $9-18$ & & & This study \\
\hline \multicolumn{6}{|l|}{ Calanus glacialis } \\
\hline Greenland Sea & 0 & $0-\sim 8$ & $15-45$ & & Hirche \& Bohrer (1987) \\
\hline Greenland Sea & $1-6^{\mathrm{c}}$ & & & & Smith (1990) \\
\hline Gulf of St. Lawrence & $\sim 0$ & & $\sim 10$ & & Tourangeau \& Runge (1991) \\
\hline Barents Sea & 1 & & & & Hirche \& Kattner (1993) \\
\hline Greenland Sea & 0 & $0-60$ & $30-70$ & & Hirche et al. (1994) \\
\hline Greenland Sea & $0-\sim 50$ & $0-70$ & $5-90$ & & Hirche \& Kwasniewski (1997) \\
\hline Barents Sea Atlantic water & $0-4$ & $0.6-4$ & $15-99$ & $0-0.4$ & This study \\
\hline Barents Sea Polar front region & - & $7-37$ & $17-77$ & $0-22$ & This study \\
\hline Barents Sea Arctic water & - & $0-42$ & & & This study \\
\hline \multicolumn{6}{|c|}{$\begin{array}{l}\text { 'Egg production during their 'start', 'main' and 'end' spawning phases } \\
\text { bAll female C. finmarchicus had immature gonads }\end{array}$} \\
\hline
\end{tabular}

chlorophyll content. The measured egg production rates are characterised by high variability (Table 4 ). Egg production rates of $C$. finmarchicus and $C$. glacialis in Atlantic water and of $C$. glacialis in the
Polar front region of the Barents Sea generally fall within the range of previously reported rates. Highest degrees of similarity are found between time series of egg production rate of $C$. finmarchicus obtained in 
Atlantic water (present study), in a north Norwegian fjord (Diel \& Tande 1992) and in the Gulf of. St Lawrence (Plourde \& Runge 1993).

In the present investigation we used the egg ratio method to obtain egg production rates (see 'Material and methods') while in the other studies referred to in Table 4, the more direct egg production method have been used (e.g. Marshall \& Orr 1952, 1953, Runge 1985). The results in Table 4 indicate that the 2 methods give similar egg production rates, a conclusion also drawn by Tourangeau \& Runge (1991) using both methods simultaneously. The sources of error, however, are very different in the 2 methods. Applying the egg ratio method to broadcast spawners causes underestimation of egg production rates when egg mortality and sinking rates of the eggs are not accounted for. Further, one has to assume that the females which are present with the eggs at a sampling site are the females having spawned the eggs. The egg production method, on the other hand, involves capture and sorting of females which are incubated for spawning under laboratory conditions. This may influence the performance of the specimens. There may also be egg cannibalism before the eggs sink through the false screen bottom usually used to separate eggs and females. Similar results obtained by the 2 methods may suggest that handling and egg cannibalism have significant effect on the results obtained by the egg production method.

Egg production of Calanus finmarchicus and $C$. glacialis in the Barents Sea occurred in chlorophyll contents much higher than those reported in the other investigations (Table 4). For example during the bloom in Atlantic water and the Polar front region chiorophyll contents varied between 150 and $500 \mathrm{mg} \mathrm{m}^{-2}$ (Figs. 2 \& 9), while in the other investigations referred to in Table 4 chlorophyll contents during the bloom usually were lower than $150 \mathrm{mg} \mathrm{m}^{-2}$ (e.g. Plourde \& Runge 1993, Hirche et al. 1994). The seemingly weak overall relationship between egg production rates and chlorophyll content may be because egg production rates increase towards an asymptote at high chlorophyll concentrationss as shown by laboratory and field data (Hirche et al. 1994, 1997). The relationship between egg production rates and chlorophyll concentrations may also have been confounded because heterotrophic microplankton can make a significant contribution to the diet of Calanus spp. (e.g. Hirche \& Kwasniewski 1997)

Pre-bloom spawning of Calanus finmarchicus and $C$. glacialis in Atlantic water started at a very low rate in late February (Table 4, Figs. 4 \& 6). In the Polar front region the pre-bloom phase was not sampled. However, both species produced eggs at considerable rates at 3 early bloom stations in April (Figs. 10 \& 12). By extrapolation from first occurrence of $\mathrm{Cl}_{\text {, }}$ using temperature dependent developmental rates according to Corkett et al. (1986), the start of the spawning for both C. finmarchicus and C. glacialis was estimated to be late March in Atlantic water and early April in the Polar front region. The later start of spawning in Atlantic water as estimated by extrapolation compared to direct observations of egg production may be due to a lower survival rate of the early spawned recrujts, as suggested by Melle \& Skjoldal (1989) based on observations of high sinking rates of the eggs spawned early in the spring. Also, sub-optimal feeding conditions during the pre-bloom period may have led to lower survival rates. Estimated start of pre-bloom spawning was later in the Polar front region than in Atlantic water, which may be due to a slower development of the parent generation of both species towards the Arctic as suggested by the stage ratio index (Figs. 4, 6, 10 \& 12). We conclude that the tendency for pre-bloom spawning is equally present in both $C$. finmarchicus and $C$. glacialis when environmental conditions (e.g. winter temperature) allows an early gonad maturation.

In the present investigation eggs of Calanus hyperboreus were found regularly from the first day of sampling in February (Fig. 8). Thus, winter spawning, which is known from previous investigations of $C$. hyperboreus (Sømme 1934, Østvedt 1955, Conover 1967, 1988, Smith 1990, Conover \& Siferd 1993, Hirche \& Niehoff 1996), was confirmed. In Vestfjorden, northern Norway, a secondary spawning occurred during the phytoplankton bloom (Somme 1934). We observed a similar increase in egg numbers during the spring bloom, indicating higher egg production rates during the bloom (Fig. 8).

Energy resources fuelling pre-bloom egg production may vary among the Calanus species. In C. hyperboreus lipids stored from the previous growth season are regarded as the most important energy source (Conover 1988, Conover \& Siferd 1993, Hirche \& Niehoff 1996). Observations of pre-bloom spawning of C. glacialis have led to the conclusion that C. glacialis has a similar spawning strategy and is using internal fat reserves from the previous feeding season for prebloom egg production (Smith 1990. Hirche \& Kattner 1993). This is supported by observations of C. glacialis spawning under $2 \mathrm{~m}$ of fast ice in the central. Canadian Arctic when the chlorophyll concentration was less than $0.1 \mathrm{\mu g} \mathrm{I}^{-1}$ (Conover 1988). On the other hand, $C$. glacialis can produce eggs by feeding on ice-algae (Tourangeau \& Runge 1991), and both C. finmarchicus and $C$. glacialis can produce eggs by feeding on heterotrophic microplankton during various parts of the phytoplankton bloom development (Ohman \& Runge 1994, Hirche \& Kwasniewski 1997. Nejstgaard et al 1997). In the Barents Sea, gut analyses showed that $C$. 
finmarchicus and C. glacialis start to feed at a low rate during the pre-bloom phase in late February in Atlantic water (Nejstgaard \& Skjoldal 1991). Thus, spawning of $C$. finmarchicus and $C$. glacialis before the bloom in the Barents Sea may be initiated and supported by low pre-bloom food concentrations rather than, or in addition to, internal fat reserves.

Spawning before the bloom may be advantageous because development through the egg and non-feeding nauplius stages, presumably NI and NII, before the bloom increases the chances of the feeding stages in exploiting the food resources during a short lasting bloom. An earlier birth may also be advantageous if the specimens can complete their life cycle within fewer growth seasons. We found $C$. hyperboreus to spawn eggs during winter which due to their dark appearance after fixation were considered to have a high fat content (Conover \& Siferd 1993). These eggs did not develop past NIII, which probably is the first feeding stage, before the initiation of the phytoplankton bloom. By allocating extra and different types of lipids to the eggs, $C$. hyperboreus seems to be specialised towards this spawning strategy (Conover \& Siferd 1993). After the initiation of the bloom the nauplii rich in fat disappeared from the samples and the first NIV were observed (Fig. 8). This may have been because $C$. hyperboreus nauplii disappeared from the samples altogether, or the nauplii produced during the bloom contained less fat. The latter possibility indicates that some individuals within the C. hyperboreus population have a reproductive strategy similar to that of C. finmarchicus and C. glacialis. With less fat deposited in their eggs and possibly shorter non-feeding survival time for eggs and nauplii, pre-bloom spawning of $C$. finmarchicus and C. glacialis is probably of limited advantage.

Egg production rates of Calanus finmarchicus and $C$. glacialis and phytoplankton biomass, as chlorophyll content, increased simultaneously at the end of May and in early June in Atlantic water (Figs. 2, 4 \& 6), and increased egg production of C. glacialis coincided with the increase of chlorophyll content in the Polar front region (Figs. $9 \& 12$ ). The close relationship between the main spawning of $C$. finmarchicus and the phytoplankton spring bloom in Atlantic water is in accordance with results obtained from time series studies in a north Norwegian fjord (Diel \& Tande 1992) and in the Gulf of St. Lawrence (Plourde \& Runge 1993). Increased rate of egg production of C. glacialis during the bloom of planktonic algae following the ice breakup in Hudson Bay, Canada, matches our results from the Polar front region (Tourangeau \& Runge 1991). Laboratory experiments have established functional relationships between food, such as diatoms, and egg production rate in C. finmarchicus (Hirche et al. 1997).
We conclude that egg production of $C$. finmarchicus and C. glacialis in Atlantic water and of C. glacialis in the Polar front region was food limited during the preand early bloom periods and then accelerated, fuelled by feeding on algal cells, during the blooms.

In the Polar front region there was a mis-match between spawning of Calanus finmarchicus and the phytoplankton bloom. Maximum spawning rate was not found at the stations with the highest chlorophyll content in April but rather at a late bloom station in July (Fig. 10). The ratio between CVI females and CV never exceeded 0.5 during the pre-bloom and bloom periods, indicating that development during winter or the previous growth season was slower in the Polar front region than in Atlantic water. The stage ratio index of C. glacialis equalled 1.0 before the bloom in the Polar front region (Fig. 12), Similarly, it has been found in other Arctic regions that the fraction of females with immature gonads during winter is higher in C. finmarchicus than in C. glacialis (Smith 1990, Hirche \& Kattner 1993, Hirche et al. 1994). This suggests that slow development causes mis-match between the phytoplankton blooms and the spawning of $C$. finmarchicus, which probably is an important reason why this species is an expatriate in the Arctic. Thus, spawning strategies of $C$. finmarchicus and $C$. glacialis seem be similar; however, $C$. finmarchicus does not seem to survive very well with its strategy in the Polar front region, probably due to low temperatures and early, short lasting blooms.

There are known sources of error that may have biased our results. For example, female mortality affects realised fecundity by shifting the relative abundance levels of females in the pre-reproductive, reproductive and post-reproductive stages (Ohman et al. 1996). Together with seasonally pulsed cohorts this may confound conclusions about food dependency of egg production rates. Also, other food particles, such as microzooplankton which is likely to increase in abundance during the bloom, may have been important for egg production rates of Calanus finmarchicus and $C$. glacialis in the Barents Sea. Mesocosm experiments have shown that heterotrophic microplankton may be the main food of $C$. finmarchicus during egg production, and that abundances of these organisms peaked during the phytoplankton bloom (Nejstgaard et al. 1997). In the Greenland Sea no relationship was found between egg production rate of C. glacialis and chlorophyll content, and feeding on microzooplankton in addition to algae was suggested to be the reason for this (Hirche \& Kwasniewski 1997). Ohman \& Runge (1994) showed that a high rate of egg production in $C$. finmarchicus can be sustained by feeding on heterotrophic microplankton. Thus, future investigations of reproduction of $C$. finmarchicus and C. glacialis should 
include abundance estimates of alternative food particles and a dietary mapping.

Temperature affects rate of development in copepodites of Calanus spp. (Corkett et al. 1986) and, thereby, length of life cycles and timing of important life history events such as reproduction. In the Norwegian Sea overwintering of $C$. finmarchicus occurs below Atlantic water at temperatures of about $-1^{\circ} \mathrm{C}$ while in the Barents Sea overwintering occurs more or less evenly distributed in the Atlantic water masses at about $3^{\circ} \mathrm{C}$ (Ostvedt 1955, Loeng 1991, Melle et al. 1993, Pedersen et al. 1995). Thus, with respect to temperature, we expect development during overwintering in the Barents Sea to be faster than in the Norwegian Sea. During the growth season temperatures are highest in the Norwegian Sea and development presumably faster than in the Barents Sea, feeding conditions not taken into consideration. If we compare stage distributions of $C$. finmarchicus when the spawning periods start, the population consisted of $60 \%$ adult females and $20 \%$ CV in the Norwegian Sea (Østvedt 1955), and only females in the Barents Sea. Even 1 mo earlier the copepodite stage ratio was close to 0.5 in the Barents Sea, corresponding to $75 \%$ females (Fig. 4). Although comparison between different years may be difficult, development of $C$. finmarchicus in Atlantic water of the Barents Sea was not delayed compared to the population in the Norwegian Sea, and a larger fraction of the Barents Sea population may have been ready to spawn when the phytoplankton bloomed. This could have been due to higher wintering temperatures in the Barents Sea, and it may have an influence on the link between primary and secondary production, and on the Barents Sea as a region of high fish production.

Diel \& Tande (1992) suggested that reduction in the ratio between CVI females and CV immediately after the main spawning in connection with the bloom could be used as an indicator of the spawning event in Calanus finmarchicus. This is supported by our results from Atlantic water (Fig. 4), where few CV of the new generation appeared before July (Fig. 5). Therefore, the reduction in the copepodite stage ratio index was most likely due to reduction in the number of females, probably because the spawning or spent females have a higher mortality rate. In the Polar front region, however, a corresponding reduction in the copepodite ratio did not take place, since adult females were not the only developmental stage left of the overwintered population before spawning, and adult females were continuously arising from a pool of CV (Fig. 10). For C. glacialis in Atlantic water the period of intensified spawning during the bloom coincided with a reduction in the copepodite ratio. In this species, however, the reduction in the ratio, in addition to the reduced numbers of females, may also be due to the high numbers of overwintered CIII and CIV moulting into CV Therefore, the stage ratio index should be used with more caution for this species.

Stage distribution of Calanus finmarchicus as revealed in the present investigation generally fitted a 1 yr life cycle (Tande et al. 1985). Stage distribution of C. glacialis indicated that both 1 and 2 yr life cycles were common (cf. MacLellan 1967, Tande et al. 1985). During late winter and spring the generation of $C$. glacialis overwintering for the first time probably were in stages CIII and CIV, and the generation overwintering for the second time were in stage CVI (Figs. $7 \&$ 11). With a 2 yr life cycle, 2 generations and many copepodite stages are involved in the wintering (e.g. Tande et al. 1985). A wide stage distribution also has been considered to reflect a prolonged spawning season within a 1 yr life cycle (Grainger 1961, MacLellan 1967, Conover 1988). In the present investigation the extreme bimodality of the copepodite stage distribution of C. glacialis after wintering indicated that development was arrested in CIV during winter (Figs. 7 \& 11). Arrested development in CIV probably serves as a mechanism to increase survival of the youngest generation during winter. With life cycles less than a year, arrested development in CIV may synchronise late and early spawners, but this would induce 2 separate spawning events, which does not seem to be advantageous as the bloom develops continuously.

Individuals of Calanus glacialis having a life cycle shorter than 2 yr may have accomplished this in 2 ways. The high numbers of CV and CVI in July in the Atlantic and Polar front regions (Figs. 7 \& 11) indicated that part of the new generation developed past CIV and was able to reproduce the next spring, having a 1 yr life cycle. Among the females spawning in July (Fig. 6) some may have developed from the overwintered CIII and CIV, thus having a life cycle of $1 \mathrm{yr}$, or a few months more than a year. The advantage of a shorter life cycle would probably come from a reduced life time mortality, as, to the late summer spawners, both conditions for egg production and feeding conditions for the recruits probably are sub-optimal.

Acknowledgements. We are grateful to Ulf. Båmstedt, Svein. Sundby, Dag Aksnes and Bjørnar Ellertsen for valuable criticism of the manuscript. We thank Kurt Tande and 2 anonymous referees for critical review of this manuscript. We thank Lena Omli, Signe Johannessen and Arne Hassel for analysing some of the zooplankton samples, and Karen Gjertsen for help with the map.

\section{LITERATURE CITED}

Aksnes DL, Blindheim J (1996) Circulation patterns in the North Atlantic and possible impact on the population of Calanus finmarchicus. Ophelia 44:7-28 
Conover RJ (1967) Reproductive cycle, early development, and fecundity in laboratory populations of the copepod Calanus hyperboreus. Crustaceana 13:61-72

Conover RJ (1988) Comparative life histories in the genera Calanus and Neocalanus in high latitudes of the northern hemisphere. Hydrobiologia 167/168:127-142

Conover RJ, Siferd TD (1993) Dark-season survival strategies for coastal zone zooplankton in the Canadian Arctic. Arctic 46:303-311

Corkett CJ, McLaren IA, Sevigny JM (1986) The rearing of the marine calanoid copepods Calanus finmarchicus (Gunnerus), C. glacialis Jaschnov and C. hyperboreus Kroyer with comment on the equiproportional rule. Syllogeus 58:539-546

Dawson JK (1978) Vertical distribution of Calanus hyperboreus in the Central Arctic Ocean. Limnol Oceanogr 24: 950-957

Diel S, Tande K (1992) Does the spawning of Calanus finmarchicus in high latitudes follow a reproducible pattern? Mar Biol 113(1):21-32

Edmondson WT (1960) Reproductive rates of rotifers in natural populations. Mem Ist Ital Idrobiol 12:21-77

Eilertsen HC (1993) Spring blooms and stratification. Nature 363:24

Eilertsen HC, Sandberg S, Tøllefsen H (1995) Photoperiodic control of diatom spore growth: a theory to explain the onset of phytoplankton blooms. Mar Ecol Prog Ser 116: $303-307$

Eilertsen HC, Taasen JP, Weslawski JM (1989) Phytoplankton studies in the fjords of West Spitsbergen: physical environment and production in spring and summer. J Plankton Res 11:1245-1260

Foyn L, Magnussen M, Seglem K (1981) Automatisk analyse av næringssalter med 'on line' databehandling. En presentasjon av oppbygging og virkemåte av systemet i bruk på Havforsknings-instituttets båter og i laboratoriet. Fisken Havet Ser B 4:1-40

Grainger EH (1961) The copepods Calanus glacialis Jaschnov and Calanus finmarchicus (Gunnerus) in Canadian ArcticSubarctic waters. J Fish Res Bd Can 18(5):663-678

Hagebo M, Rey $F$ (1984) Lagring av sjøvann til analyse av næringssalter. (Storage of seawater for nutrients analysis.) Fisken Havet 4:1-12

Halldal P (1953) Phytoplankton investigations from weather ship $M$ in the Norwegian Sea, 1948-49. Hvalrådets Skr 38: $1-91$

Hassel A (1986) Seasonal changes in zooplankton composition in the Barents Sea, with special attention to Calanus spp. (Copepoda). J Plankton Res 2:329-339

Hassel A, Skjoldal HR, Gjøsæter H, Loeng H, Omli L (1991) Impact of grazing from capelin (Mallotus villosus) on zooplankton: a case study in the northern Barents Sea in August 1985. In: Sakshaug E, Hopkins CCE, Øritsland NA (eds) Proc of the Pro Mare Symp Polar Mar Ecol. Trondheim, 12-16 May 1990. Polar Res 10:371-388

Hirche HJ (1990) Egg production of Calanus finmarchicus at low temperature. Mar Biol 106:53-58

Hirche HJ (1991) Distribution of dominant copepod species in the Greenland Sea during fall. Polar Biol 11:351-362

Hirche HJ (1997) Life cycle of the copepod Calanus hyperboreus in the Gireenland Sea. Mar Biol 128:607-618

Hirche HJ, Bohrer RN (1987) Reproduction of the Arctic copepod Calanus glacialis in Fram Strait. Mar Biol 94:11-18

Hirche HJ, Hagen W, Mumm N, Richter C (1994) The Northeast Water Polynya, Greenland Sea III. Meso- and macrozooplankton distribution and production of dominant herbivorous copepods during spring. Polar Biol 14:491-503
Hirche HJ, Kattner G (1993) Egg production and lipid content of Calanus glacialis in spring: indication of a food-dependent and food-independent reproductive mode. Mar Biol $117: 615-622$

Hirche HJ, Kwasniewski S (1997) Distribution, reproduction and development of Calanus species in the Northeast Water in relation to environmental conditions. J Mar Syst 10:299-317

Hirche HJ, Meyer U, Niehoff B (1997) Egg production of Calanus finmarchicus: effect of temperature, food and season. Mar Biol 127:609-620

Hirche HJ, Mumm N (1992) Distribution of dominant copepods in the Nansen Basin, Arctic-Ocean, in summer. Deep Sea Res 39:485-505

Hirche HJ, Niehoff B (1996) Reproduction of the Arctic copepod Calanus hyperboreus in the Greenland Sea-field and laboratory observations. Polar Biol 16:209-219

Jaschnov WA (1958) Origin of the species Calanus finmarchicus s.l. Zhool Zh 9

Jaschnov WA (1970) Distribution of Calanus species in the seas of the Northern Hemisphere. Int Rev Ges Hydrobiol Hydrogr 55:179-212

Johnson MW (1963) Zooplankton collections from the high polar basin with special reference to the copepoda. Limnol Oceanogr 8:89-102

Loeng $H$ (1991) Features of the physical oceanographic conditions of the Barents Sea. In: Sakshaug E, Hopkins CCE, $\varnothing$ ritsland NA (eds) Proc Pro Mare Symp Polar Mar Ecol, Trondheim, 12-16 May 1990. Polar Res 10:5-18

MacLellan DC (1967) The annual cycle of certain calanoid copepods in West Greenland. Can J Zool 45:101-115

Manteufel BP (1938) Description of the changes occurring regularly in the plankton of the Barents Sea. Fisheries Research Board of Canada, Ottawa, Translation Series No. 1780

Marshall SM, Orr AP (1952) On the biology of Calanus finmarchicus VII. Factors affecting egg production. J Mar Biol Assoc UK 30:527-547

Marshall SM, Orr AP (1953) Calanus finmarchicus: egg production and egg development in Tromse Sound in spring. Acta Borealia A Scienta 5:1-21

Matthews JBL, Hestad L, Bakke JLW (1978) Ecological studies in Korsfjorden, western Norway. The generations and stocks of Calanus hyperboreus and C. finmarchicus in 1971-1974. Oceanol Acta 1:277-284

Melle W, Knutsen T, Ellertsen B, Kaartvedt S, Noji T (1993) $\varnothing$ kosystemet i ostlige Norskehavet; sokkel og dyphav. Havforskningsinstituttet, Bergen. Rapport fra Senter for Marint Miljo 4. ISSN $0804-2128$

Melle W, SkjoIdal HR (1989) Zooplankton reproduction in the Barents Sea: vertical distribution of eggs and nauplii of Calanus finmarchicus in relation to spring phytoplankton development. In: Ryland JS, Tyler PT (eds) Reproduction, genetics and distributions of marine organisms. Olsen \& Olsen, Fredensborg, p 137-145

Miller CB, Cowles TJ, Wiebe PH, Copley NJ, Grigg H (1991) Phenology in Calanus finmarchicus; hypotheses about control mechanisms. Mar Ecol Prog Ser 72:79-91

Nejstgaard JC, Gismervik. I, Solberg P (1997) Feeding and reproduction by Calanus finmarchicus, and microzooplankton grazing during mesocosm blooms of diatoms and the coccolithophore Emiliana huxleyi. Mar Ecol Prog Ser $147: 197-217$

Nejstgaard JC, Skjoldal HR (1991) Seasonal feeding strategies of calanoid copepods in the Western Barents Sea. In: Nejstgaard JC. Feeding ecology of Calanoid copepods in the Barents Sea. Cand scient thesis, University of Bergen, p 15-30 
Ohman MD, Aksnes DL, Runge JA (1996) The interrelationship of copepod fecundity and mortality. Limnol Oceanogr 41:1470-1477

Ohman MD, Runge JA (1994) Sustained fecundity when phytoplankton resources are in short supply: omnivory by Calanus finmarchicus in the Gulf of St. Lawrence. Limnol Oceanogr 39:21-36

Ostvedt OJ (1955) Zooplankton investigations from weathership $\mathrm{M}$ in the Norwegian Sea 1948-49. Hvalrådets Skr 40: $1-93$

Pedersen G, Tande K, Ottesen GO (1995) Why does a component of Calanus finmarchicus stay in the surface waters during the overwintering period in high latitudes? ICES J Mar Sci 52:523-531

Plourde S, Runge JA (1993) Reproduction of the planktonic copepod Calanus finmarchicus in the Lower St. Lawrence Estuary: relation to the cycle of phytoplankton production and evidence for a Calanus pump. Mar Ecol Prog Ser 102: $217-227$

Rey F, Loeng H (1985) The influence of ice and hydrographic conditions on the development of phytoplankton in the Barents Sea. In: Gray JS, Christensen ME (eds) Marine biology of polar regions and effect of stress on marine organisms. Proc 18th Eur Mar Biol Symp, Oslo, 14-20 August 1983. John Wiley \& Sons Lid, Chichester, p 49-63

Rudyakov YA (1983) Vertical distribution of Calanus hyperboreus (Copepoda) in the Central Arctic Basin. Oceanology Academy of Sciences of the USSR 23:249-254

Runge JA (1985) Egg production rates of Calanus finmarchicus in the sea off SW Nova Scotia. Arch Hydrobiol 21: $33-40$

Sakshaug E, Skjoldal HR (1989) Life at the ice edge. Ambio $18: 60-67$

Sambrotto RN, Niebauer HJ, Goering JJ, Iverson RI (1986) Relationships among vertical mixing, nitrate uptake, and phytoplankton growth during the spring bloom in the Southeast Bering Sea middle shelf. Cont Shelf Res 5: $161-198$

Skjoldal HR, Hassel A, Rey F, Loeng H (1987) Spring phytoplankton development and zooplankton reproduction in the central Barents Sea in the period 1979-1984. In: Loeng $H$ (ed) The effect of oceanographic conditions on the distribution and population dynamics of commercial fish

Editorial responsibility: Otto Kinne (Editor), Oldendorf/Luhe, Germany stocks in the Barents Sea. Proc 3rd Soviet-Norwegian Symp, Murmansk, 26-28 May 1986. Institute of Marine Research, Bergen, p 59-89

Skjoldal HR, Rey F (1989) Pelagic production and variability of the Barents Sea ecosystem. In: Sherman K, Alexander L (eds) Biomass yields and geography of large marine ecosystems. AAAS Sel Symp 111:241-286

Smith SL (1990) Egg production and feeding by copepods prior to the spring bloom of phytoplankton in Fram Strait, Greenland Sea. Mar Biol 106:59-69

Solemdal P, Ellertsen B (1984) Sampling fish larvae with large pumps; quantitative and qualitative comparisons with traditional gear. Flodevigen Rapportser 1:335-363

Somme JD (1934) Animal plankton of the Norwegian coast waters and the open sea. Production of Calanus finmarchicus (Gunner) and Calanus hyperboreus (Krøyer) in the Lofoten area. FiskDir Skr Ser Havunders 9

Sverdrup HU (1953) On conditions for the vernal blooming of phytoplankton. J Cons Perm Int Explor Mer 18:287-295

Tande KS (1991) Calanus in North Norwegian f.jords and in the Barents Sea. In: Sakshaug E, Hopkins CCE, Øritsland NA (eds) Proc Pro Mare Symp Polar Marine Ecol, Trondheim, 12-16 May 1990. Polar Res 10:389-407

Tande KS, Hassel A, Slagstad D (1985) Gonad maturation and possible life cycle strategies in Calanus finmarchicus and Calanus glacialis in the northwestern part of the Barents Sea. In: Gray JS, Christensen ME (eds) Marine biology of polar regions and effect of stress on marine organisms. Proc 18th Eur Mar Biol Symp, Oslo, 14-20 August 1983 John Wiley \& Sons Ltd, Chichester, p 141-155

ter Braak CJF, Prentice IC (1988) A theory of gradient analysis. Adv Ecol Res 18:271-317

Tourangeau S, Runge JA (1991) Reproduction of Calanus glacialis in relation to an ice microalgal bloom in the southeastern Hudson Bay. Mar Biol 106:227-234

Townsend DW, Keller MD, Sieracki ME, Ackleson SG (1992) Spring phytoplankton blooms in the absence of vertical water column stratification. Nature 360:59-62

Wiborg KF (1954) Investigations on zooplankton in coastal and offshore waters off western northwestern Norway. FiskDir Skr Ser Havunders 11(1):1-246

Wilkinson L (1992) SYSTAT: Statistics, Version 5.2. SYSTAT Inc, Evanston, IL

Submitted: December 8, 1997; Accepted: April 3, 1998 Proofs received from author(s): July 6, 1998 